\title{
Effect of Different Dietary Protein Levels on Survival Rate and Growth Perfor- mance of Guppy (Poecilia reticulata)
}

\author{
Abdalbast H. Fadel ${ }^{*}$, Awad J. Lamin ${ }^{1}$, Randa Rajab Ali ${ }^{1}$ and Karema A. Momen ${ }^{2}$ \\ ${ }^{1}$ Department of Marine Resources, Omar Al-Mukhtar University, Al Bayda, Libya. \\ ${ }^{2}$ Department of Environment Science, Omar Al-Mukhtar University, Al Bayda, Libya
}

Received: 27 April 2021/ Accepted: 31 May 2021

Doi: https://doi.org/10.54172/mjsc.v36i2.42

\begin{abstract}
This study was carried out to evaluate the growth response of guppy Poecilia reticulata to different dietary protein levels. A total of 72 fry of guppy fish of an initial body weight $0.365 \pm$ $0.01 \mathrm{~g}$ were distributed randomly into $60 \mathrm{~L}$ aquaria at the density rate of $0.05 \mathrm{~g} / \mathrm{L}$. Fish were fed to satiation twice daily for eight weeks with diets containing different dietary protein levels $(20 \%$, $30 \%$, or $40 \%$.). The survival rate of guppy was unaffected by increasing dietary protein levels. At the end of the experiment, weight gains (g) ranging from 1.93 to 3.55 were obtained corresponding to $20 \%$ and $40 \%$ crude protein respectively. The growth performance and feeding efficiencies were significantly improved $(\mathrm{P}<0.05)$ by increasing dietary protein levels. However, no significant difference $(P>0.05)$ was observed in the specific growth rate of fish that were fed $20 \%$ and $30 \%$ dietary protein levels. The value of the condition factor was significantly high in fish fed at $40 \%$ dietary protein. It can be concluded that a $40 \%$ dietary protein level is recommended for guppy fish.
\end{abstract}

Keywords: Guppy; Protein Level; Survival Rate; Growth Performance

\section{INTRODUCTION}

The ornamental fish trade plays an important role in the global economy, as millions of recreational fish are sold annually around the world (AOAC, 1997; Kumaratunga \& Radampola, 2019). The major countries participating actively in this trade are the USA, Australia, Europe, Singapore, Japan, the Philippines, Sri Lanka, and Indonesia. The ornamental fish business has been estimated at more than 8 billion USD (Jayalal et al., 2016). Despite the economic significance of this sector, studies of the nutritional requirements of ornamental fish are rarely reported (Lovell, 2000). Most of the nutrition information used for ornamental fish species is based on results about edible fish. It is important to know the nutritional requirements of ornamental fish species, that one may provide a diet rich in essential nutrients to ensure the efficient growth of ornamental fish from the stage of growth to the stage of hatching and reproduction (Hoseini et al., 2017; Masrizal et al., 2015). In general, protein is considered the most important and most expensive component of fish feed, which often accounts for about $60 \%$ of the cost of fish feeds (Khattab et al., 2001). Protein affects the fish's growth and production cycle. Maximum feed proteins provide the maximum growth rate, thus maximizing the benefits to fish farmers (Hoseini et al., 2018). The dietary protein requirements for freshwater ornamental fish are from 30 to $50 \%$ in omnivores and carnivores, respectively (Hardy (2003)).

Dietary protein requirements for many ornamental species are still unknown. The guppy fish (Poecilia reticulata) is one of the common ornamental fishes that is widely produced in many countries around the world due to its low prices and adaptability. This

*Corresponding Author: Abdalbast H. Fadel.basitfadel@yahoo.com, Department Marine Resources, Omar Al-Mukhtar University, Al Baida, Libya. 
study aimed to investigate the effect of increasing dietary protein on the survival rate, growth performance, and feed utilization of the guppy.

\section{MATERIAL AND METHODS}

Experimental diets preparation: Three experimental diets were formulated based on a basal diet formulated from practical ingredients to satisfy all known nutrient requirements Poecilia reticulata according to (NRC, 1993).

The formula and analyzed proximate composition of the three experimental diets are shown in Table (1).

The ingredients were hammer milled to a fine powder and then sieved through a mesh size of $0.5 \mathrm{~mm}$ diameter. The dry ingredients were mixed for $15 \mathrm{~min}$, and then the lipid was added slowly and further mixed for another $15 \mathrm{~min}$. After which, the distilled water was added at $25 \%$ of the total ingredient weight. Three different experimental diets were formulated with an increased dietary protein content to make $20 \%, 30 \%$, and $40 \%$ crude protein concentrations. The proximate composition of diets was determined according to standard AOAC (1997) methods.

Table (1): Ingredient and proximate composition of the experimental diets.

\begin{tabular}{lccc}
\hline \multicolumn{1}{c}{ Ingredients } & \multicolumn{3}{c}{$\%$} \\
\hline $\begin{array}{l}\text { Dietary protein level } \\
\text { (\% dry weight) }\end{array}$ & 20 & 30 & 40 \\
Fishmeal & 17 & 27 & 36 \\
Soybean meal & 26 & 37 & 38 \\
Ground corn & 48 & 27 & 17 \\
Soy oil & 7 & 7 & 7 \\
Vitamins & 1 & 1 & 1 \\
Mineral premix & 1 & 1 & 1 \\
\hline Proximate composition (\% dry weight) \\
\hline Dry matter & 93.12 & 93.91 & 94.63 \\
Crude protein & 20.81 & 30.56 & 40.11 \\
Crude lipid & 6.14 & 6.88 & 6.65 \\
Ash & 6.65 & 7.1 & 7.82 \\
\hline \hline
\end{tabular}

Experimental setup: A total number of 72 Guppy ( $P$. reticulata) fry were purchased from local suppliers of aquarium fish shops, Libya, and placed in a $500 \mathrm{~L}$ fiberglass tank. Fish were randomly and equally stocked into nine rectangular glass aquaria $(80 \times 35 \times 50 \mathrm{~cm})$ of $60 \mathrm{~L}$ dechlorinated fresh tap water for a 20 days acclimation period and fed with a commercial diet designed for ornamental fishes. All guppy in the aquaria were weighed individually at the start of the experiment. At the start of the experiment, each guppy fry was weighed individually, and had an average body of $0.365 \pm 0.01 \mathrm{~g}$. The aquaria were then randomly designated to each dietary protein treatment in triplicates. All fish were fed the experimental diets twice daily (9:00 a.m. and 4:00 p.m) until apparent satiation (Belal et al., 2015; McGoogan \& Reigh, 1996). Each aquarium received gentle aeration with natural photoperiod (13 hours light 11 hours dark) and an ambient temperature of $\left(26-28^{\circ} \mathrm{C}\right)$. The water parameters were measured daily. The $\mathrm{pH}$ was measured using a digital $\mathrm{pH}$ probe (Jenway 3305), water temperature and dissolved oxygen were measured using OXI 92. $\mathrm{pH}$ and the dissolved oxygen were 7.88.1 and $4.8-5.6 \mathrm{mg} / \mathrm{l}$ respectively. At every 72 hours, aquarium water exchange was performed, and the aquaria were thoroughly cleaned. The fish was fasted one day before ending the feeding trial.

Measurement of growth parameters : During the study, length $(\mathrm{cm})$ and weight $(\mathrm{g})$ of individual guppy fry were measured and recorded on the first day and then every 72 hours. After 8 weeks, the fish were mildly anesthetized with clove oil, and then the length and weight of individual guppies were recorded. The following parameters were estimated:

Growth performance: The percent weight gain (WG), average daily gain (ADG), and specific growth rate (SGR) (Han et al. 2015) were calculated by the following equations: 
$\mathrm{WG}(\%)=\left[\left(\mathrm{BWf} \_\mathrm{BWi}\right) / \mathrm{BWi}\right] \times 100$

$\operatorname{ADG}(\mathrm{g} /$ day $)=\left(\overline{\mathrm{BWf}} \mathrm{BWi}_{-} / \mathrm{T}\right.$

$\operatorname{SGR}(\% /$ day $)=\left[\ln \left(\mathrm{BW} \mathrm{f}_{-} \operatorname{lnBWi}\right) / \mathrm{T}\right] \times 100$

Where, BWf, BWi, and $\mathrm{T}$ are the final body weight, the initial body weight and time in days, respectively, and all weights are in grams $(\mathrm{g})$.

Condition Factor (CF) (Rad et al., 2012) was calculated by the following equation:

$\mathrm{CF}=[\mathrm{TW}(\mathrm{g}) / \mathrm{L}(\mathrm{cm} 3)] \times 100$

Where, TW and L are the total body weight

$(\mathrm{g})$ and total length $(\mathrm{cm})$, respectively.

Daily feed intake (FI) and Feed conversion ratio (FCR) were calculated according to ( $\operatorname{Rad}$ et al. 2012) by the following equations:

$(\mathrm{FI}, \mathrm{g} / \mathrm{d} / \mathrm{fish})=$ Diet consumed $\times 100 /$ duration in days /fish number per tank

$(\mathrm{FCR}, \mathrm{g})=[$ dry weight of feed $(\mathrm{g}) /$ wet weight gain $(\mathrm{g})]$.

The percent of survival was calculated according to (Han et al. 2015) by the following equation:

Survival $(\%)=\left(\mathrm{N}_{f} / \mathrm{N}_{i}\right) \times 100$

Where, $\mathrm{N}_{s}$ and $\mathrm{N}_{i}$ are the number of surviving fish and the initial number of fish, respectively

Statistical analysis: All data were presented as means ( \pm standard deviation). A one-way analysis of variance (ANOVA) was utilized for the data analyses, after prior confirmation of homogeneity and normality. Statistical significance at $\mathrm{P}<0.05$ was used and means were separated using Duncan's multiple range tests to determine differences between treatments. The SPSS version 22.0 was used for all statistical analyses.

\section{RESULTS AND DISCUSSION}

The proximate composition of experimental diets (Table 1) showed that the dry matter, lipid, and ash were not significantly different $(\mathrm{P}<0.05)$ between the experimental diets used, while the protein content was significantly different depending on the formulation.
Guppies readily accepted all experimental diets and were observed to feed voraciously throughout the experiment. The fish growth performance, feed conversion ratio (FCR), and weight gain significantly increased $(\mathrm{P}<$ $0.05)$ by the increase in protein content in experimental diets (Table 2). However, no significant differences were observed in SGR among fish fed diets containing $20 \%$ or $30 \%$ dietary protein levels compared to fish fed diets containing a 40\% dietary protein level. The fish survival was very high for all groups with no significant differences among them (Figure 1).

Table (2): Growth performance and feed utilization of guppy, fed diets with different protein levels for 8 weeks.

\begin{tabular}{lccc}
\hline \hline Parameter & \multicolumn{3}{c}{ Dietary protein level (\%) } \\
\cline { 2 - 4 } & 20 & 30 & 40 \\
\hline $\begin{array}{l}\text { Initial } \\
\text { weight(g) }\end{array}$ & $0.364 \pm 0.00$ & $0.365 \pm 0.00$ & $0.365 \pm 0.00$ \\
$\begin{array}{l}\text { Final weight } \\
\text { (g) }\end{array}$ & $2.28 \pm 0.20^{\mathrm{c}}$ & $2.70 \pm 0.22^{\mathrm{b}}$ & $3.91 \pm 0.15^{\mathrm{a}}$ \\
ADG (g) & $1.93 \pm 0.21^{\mathrm{c}}$ & $2.33 \pm 0.22^{\mathrm{b}}$ & $3.55 \pm 0.15^{\mathrm{a}}$ \\
$\begin{array}{l}\text { Weight gain } \\
\text { (\%) }\end{array}$ & $527.91 \pm 66.3^{\mathrm{c}}$ & $639.480 \pm 57.3^{\mathrm{b}}$ & $972.47 \pm 35.7^{\mathrm{a}}$ \\
$\begin{array}{l}\text { Feed conver- } \\
\text { sion ratio }\end{array}$ & $2.83 \pm 0.29^{\mathrm{a}}$ & $2.21 \pm 0.21^{\mathrm{b}}$ & $1.20 \pm 0.00^{\mathrm{c}}$ \\
$\begin{array}{l}\text { Specific } \\
\text { growth rate }\end{array}$ & $0.57 \pm 0.18^{\mathrm{b}}$ & $0.65 \pm 0.07^{\mathrm{b}}$ & $0.98 \pm 0.03^{\mathrm{a}}$ \\
Feed intake & $7.31 \pm 0.52^{\mathrm{a}}$ & $6.04 \pm 0.43^{\mathrm{b}}$ & $3.58 \pm 0.04^{\mathrm{c}}$ \\
\hline \hline
\end{tabular}

Mean \pm SE values within the same row and followed by different superscripts are significantly different $(\mathrm{p}<.05)$.

Dietary protein plays an important role in fish nutrition and it immediately affects fish growth performance and reproduction (Oliva - Teles, 2012). When fish are fed diets containing surplus levels of dietary protein, it might cause decreased growth and health obstruction because of raised amino acid 


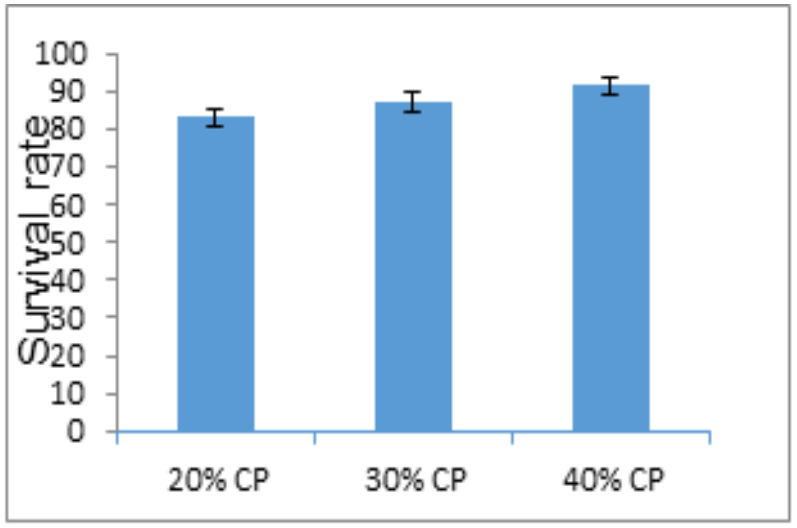

Figure 1: Survival rate (\%) of guppy fed diets with different protein levels.

Catabolism. Also, the production of high levels of ammonia and higher energy expenditure to deaminize excessive amino acids (Jiang et al., 2016; Melo et al., 2006). However, sub-optimal protein levels are unsuccessful in meeting the fish requirements for growth, and thus this clarifies the lower growth rate and feed efficiency in diets containing low levels of dietary protein (Bowyer et al., 2013).

In the present study weight gain and FCR had significantly varied among all experimental diets. The best weight gain and FCR were obtained from the fish fed a diet containing a $40 \%$ dietary protein level. Which had better growth and the best FCR. These results agreed with the results of (AOAC, 1997; Baishya et al., 2012). Also, (Dahlgren (1980)) found that the better total body weight of guppy Poecilia reticulafa was obtained at high dietary protein levels $(31 \%$ and $47 \%$ ) rather than $15 \%$ protein. In this current study, The SGR value of the fish fed with the diet containing $40 \%$ protein content was found significantly higher than that of the other two groups, which indicates that the nutrients available in the diet containing 40\% protein content fulfilled the dietary requirement of guppy to grow faster than the other two groups. These findings are in agreement with Kithsiri et al. (2010) who found that SGR increased with increasing dietary pro- tein content from $18 \%$ to $43 \%$ in the female guppy, Poecilia reticulata. In this study, feed intake was significantly influenced by dietary protein levels. Fish needs diets with a high level of protein content because of their bad utilization of carbohydrates as an energy source, thus the adequate supply of dietary protein is needed for fast growth (Lovell, 2000).

The condition factor (CF) that shows the level of wellbeing of the fish is based on a relationship between length and weight (Nehemia et al., 2012). The CF of fish is influenced by several circumstances such as stress, sex, season, availability of feed, and other water quality parameters (Khallaf et al., 2003). If the $\mathrm{CF}$ value is high, this means that the fish has achieved a better health condition. In this study, the condition factor was significantly increased with increasing dietary protein levels (Figure 2). This result agrees with (Khattab et al. (2001)) who reported that the condition factor in Nile tilapia significantly increased with increased dietary protein levels.

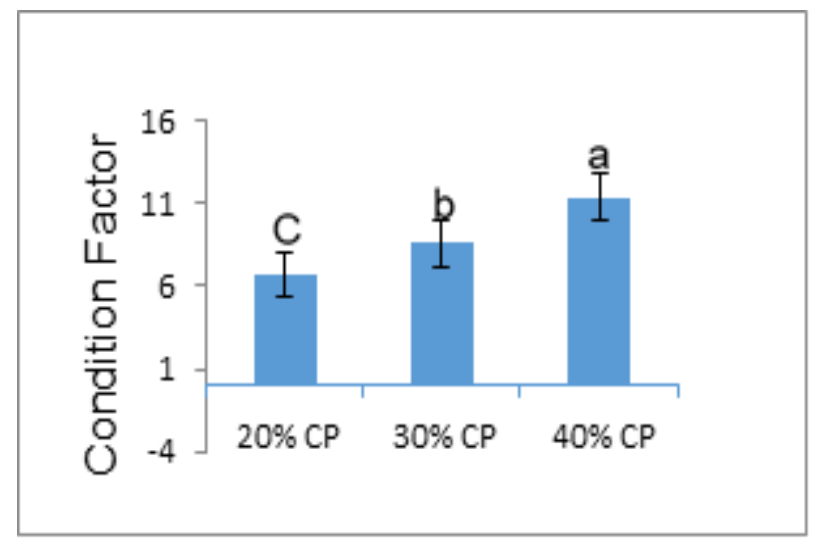

Figure 2: Condition factor of guppy fed different levels of crude protein (CP) diet.

They also added that, a high level condition factor indicated the healthy growth of fish, which is desirable for ornamental fish farms. In conclusion, a dietary protein level of $40 \%$ is necessary for maximum growth and a better condition factor for guppy fish. 


\section{REFERENCES}

AOAC. (1997). Official Methods of Analysis of AOAC International. AOAC International, Arlington.

Baishya, S., Phukan, B., Rajbongshi, A., \& Bordoloi, R. (2012). Growth Performance of Snakeskin Gourami, Trichogaster pectoralis(Regan, 1910) Using Different Dietary Protein Levels. Environment and Ecology, 30(3), 554557.

Belal, E., El-Tarabily, A., Kassab, A., AbdelFattah, M., \& Rasheed, N. (2015). Evaluation of date fiber as feed ingredient for Nile tilapia Oreochromis niloticus fingerlings. Journal of Aquaculture Research and Development, 6(3).

Bowyer, J. N., Qin, J. G., \& Stone, D. A. (2013). Protein, lipid and energy requirements of cultured marine fish in cold, temperate and warm water. Reviews in Aquaculture, 5(1), 10-32.

Dahlgren, B. (1980). The effects of three different dietary protein levels on the fecundity in the guppy, Poecilia reticulata (Peters). Journal of fish Biology, 16(1), 83-97.

Hardy, R. (2003). Introduction to the special issue on 'Ornamental fish'. Aquaculture Research, 34(11), 903-903.

Hoseini, S., Hosseini, S., Eskandari, S., \& Amirahmadi, M. (2018). Effect of dietary taurine and methionine supplementation on growth performance, body composition, taurine retention and lipid status of Persian sturgeon, Acipenser persicus (Borodin, 1897), fed with plant - based diet. Aquaculture Nutrition, 24(1), 324-331.
Hoseini, S. M., Hosseini, S. A., Eskandari, S., Amirahmadi, M., \& Soudagar, M. (2017). The effect of dietary taurine on growth performance and liver histopathology in Persian sturgeon, Acipenser persicus (Borodin, 1897) fed plant - based diet. Aquaculture Research, 48(8), 4184-4196.

Jayalal, L., Sruthi, P., \& Gopal, N. (2016). Workspace of women in the small-scale ornamental fish value chain in Kerala.

Jiang, S., Wu, X., Luo, Y., Wu, M., Lu, S., Jin, Z., \& Yao, W. (2016). Optimal dietary protein level and protein to energy ratio for hybrid grouper (Epinephelus fuscoguttatus 우 $\times$ Epinephelus lanceolatus $\sigma^{7)}$ juveniles. Aquaculture, $465,28-36$.

Khallaf, E. A., Galal, M., \& Authman, M. (2003). The biology of Oreochromis niloticus in a polluted canal. Ecotoxicology, 12(5), 405-416.

Khattab, Y., Abdel-Tawwab, M., \& H Ahmad, M. (2001). Effect of protein level and stocking density on growth performance, survival rate, feed utilization and body composition of Nile tilapia fry (Oreochromis niloticus L.). Egyptian Journal of Aquatic Biology and Fisheries, 5(3), 195-212.

Kithsiri, H. P., Sharma, P., Zaidi, S. S., Pal, A., \& Venkateshwarlu, G. (2010). Growth and reproductive performance of female guppy, Poecilia reticulata (Peters) fed diets with different nutrient levels. Indian Journal of Fisheries, 57(1), 6571.

Kumaratunga, P., \& Radampola, K. (2019). Effect of different commercial feeds on growth and reproductive performance of Guppy, Poecilia reticulata Peters. 
Journal of the University of Ruhuna, $7(1)$.

Lovell, R. (2000). Nutrition of ornamental fish. Kirk's current veterinary therapy XIII: small animal practice., 1191-1196.

Masrizal, U. Z., Zein, M., \& Bulanin, U. (2015). Effect of energy, lipid and protein content in broodstock diets on spawning fecundity and eggs quality of giant gourami (Ospheronemus gouramy Lac). Pakistan J Nutr, 14(7), 412-416.

McGoogan, B. B., \& Reigh, R. C. (1996). Apparent digestibility of selected ingredients in red drum (Sciaenops ocellatus) diets. Aquaculture, 141(3-4), 233-244.

Melo, J. F. B., Lundstedt, L. M., Metón, I., Baanante, I. V., \& Moraes, G. (2006). Effects of dietary levels of protein on nitrogenous metabolism of Rhamdia quelen (Teleostei: Pimelodidae). Comparative Biochemistry and Physiology Part A: Molecular \& Integrative Physiology, 145(2), 181187.

Nehemia, A., Maganira, J. D., \& Rumisha, C. (2012). Length-Weight relationship and condition factor of tilapia species grown in marine and fresh water ponds. Agriculture and Biology Journal of North America, 3(3), 117-124.

NRC. (1993). Nutrient requirements of fish. National Academies Press.

Oliva - Teles, A. (2012). Nutrition and health of aquaculture fish. Journal of fish diseases, 35(2), 83-108.

Rad, M., Zakeri, M., Yavari, V. and Mosavi, S. (2013): Effect of different levels of dietary supplementation of Saccharomyces cerevisiae on Growth Performance, Feed Utilization and Body Biochemical Composition of Nile Tilapia (Oreochromis niloticus) Fingerlings. World Journal of Fish and Marine Sciences, Vol.( 5), Vol. (1), Pp. 88-95.

Statistical Analysis Systems (SAS) (2009): SAS Program Ver. 8,2, SAS institute incorporation, Cary, NC27513 USA. 
تأثير المستويات المختلفة للبروتين الغذائي على معدل البقاء، وأداء النمو لأسماك الجويي

\section{Poecilia reticulata}

عبدالباسط حسين إبراهيم فضيل1"، عوض جاداله لامين ، رندة رجب علي 1 وكريمة المبروك مؤمن2 2

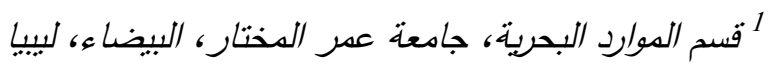

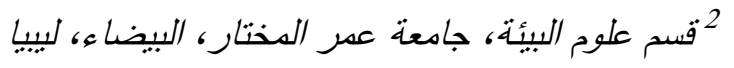

تاريخ الاستلام: 27 أبريل 2021 / تاريخ القبول: 31 مايو 2021 https://doi.org/10.54172/mjsc.v36i2.42:Doi

المستخلص : أجريت هذه الدراسة لتقييم استجابة نمو أسماك الجوبي لمستويات مختلفة من البروتين الغذائي، وزعت اثثان وسبعون من زريعة أسماك الجوبي بوزن إبتدائي 0.365 جم بشكل عشوائي في كل حوض (حجم 60 لتر)، بمعدل كثافة 0.05 جم/لتر ، غذيت الأسمالك إلى مستوى الثبع مرنين يوميًا لمدة ثمانية أسابيع على وجبات تحنوي على مستويات مختلفة من البروتين الغذائي

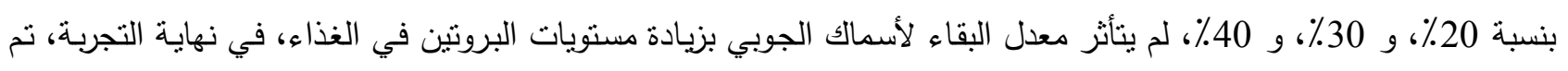

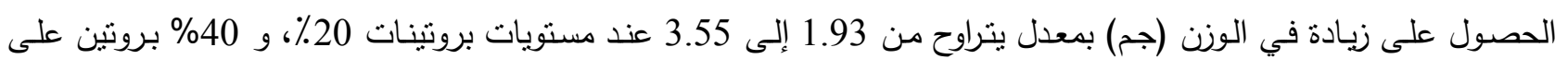
النوالي، لوحظ تحسن أداء النمو، وكفاءة التغذية معنوياً (P (P >0.05) عن طريق زيادة مستويات البروتين في الغذاء، ومهع ذلك لم

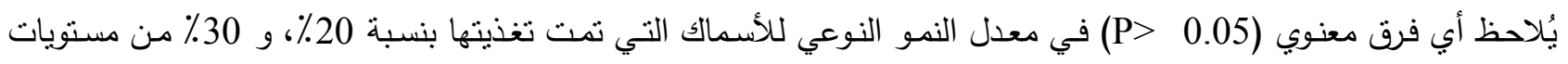

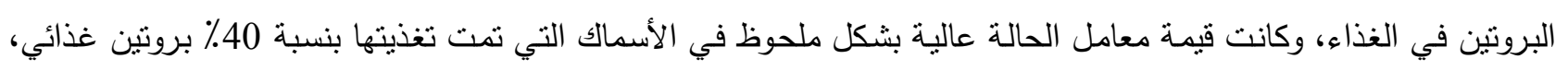
نستتنج أن مستوى البروتين الغذائي بنسبة 40٪ يوصى به به لأسماك الجوبي. الكلمات المفتاحية: أسماك الجوبي، مستوى البروتين، معدل البقاء، أداء النمو. 